\title{
REVIEW
}

\section{Monoclonal and polyclonal antibodies production - preparation of potent biorecognition element}

\author{
Miroslav Pohanka \\ Centre of Advanced Studies, Faculty of Military Health Sciences, University of Defense, Hradec Králové, \\ Czech Republic
}

Received $14^{\text {th }}$ June 2009.

Revised $3^{\text {rd }}$ August 2009.

Published online $3^{\text {rd }}$ September 2009.

\begin{abstract}
Summary
Antibodies are macromolecular structures with a high affinity to a molecule called the antigen. Though the natural aim of antibodies is the protection of the body from pathogens, they have been found to play a useful part in a number of specific treatments and diagnoses. This wider role for antibodies extends to assays where antibodies provide a recognition capability improving available physical methods. Photometrical methods such as ELISA or flow cytometry and electrochemical, optical or piezoelectric immunosensors (biosensors) are typical examples. The present review summarizes facts about the parameters and the production of antibodies. The structure of immunoglobulins, and the production and purification of monoclonal and polyclonal antibodies are described in four chapters. The review was written in order to collect the available knowledge on antibodies into one study improving orientation in this field for anyone wanting to construct immunoassays.
\end{abstract}

Key words: antibody; immunoglobulin; biosensor; polyclonal; monoclonal; immunoassay

\section{INTRODUCTION}

Antibodies play an important role not only in vivo but also in vitro in the detection of a large number of analytes; they represent recognition elements able to selectively recognize multiple analytes. Antibodies are employed in a large number of methods from chromatographic and electrophoretic to classical immuno-methods such as enzyme-linked immunosorbent assay (ELISA), dot blot

Miroslav Pohanka, Centre of Advanced Studies, Faculty of Military Health Sciences, University of Defence, Třebešská 1575, 50001 Hradec Králové, Czech Republic rau@atlas.cz

谓 $\quad+420973273582$

且 $\quad+420465635942$ immunobinding assays, electrochemiluminescence, time-resolved fluorescence, and several microscopic techniques. Flow cytometry is a method suitable for the measurement of immune response associated cells (Pasupathi et al. 2008). Actually, the construction of immunosensors is another promising way of employing antibodies for analytical purposes (Pohanka and Skládal 2008). This novel dimension of the analytical role of antibodies arose from the association of antibodies with nanoparticles (Tejral et al. 2009).

Some properties of antibodies, such as sensitivity, cross-reactivity and specificity, are important. These characteristics of a given antibody can predict the properties of methods employing it or the arrangements in which the antibody will be included. The sensitivity of an immunoassay is probably the most important parameter depending on antibody properties. Better sensitivity is logically achieved with higher affinity antibodies (Nimmo et al. 1984). 
Cross-reactivity is the interaction between the paratope of an antibody and a similar epitope or identical epitope presented on different antigens, and it plays a qualitative role in immunoassays. The ideal antibody exhibits minimal or no cross-reactivity and maximal sensitivity. The last important parameter is specificity. It is a function of affinity (avidity for polyclonal antibody) and cross reactivity, and the lack of specificity may lead to false positive or negative results. An antibody with high cross-reactivity and low specificity will predict false positive results with a consequent impact on assay performance.

\section{THE STRUCTURE OF ANTIBODIES}

Five types of immunoglobulins are normally present in the human body: IgG (above 75\% from all immunoglobulins; in healthy human serum it is present in concentrations of $8-18 \mathrm{~g} / \mathrm{l}), \operatorname{IgM}(5-10 \%)$, $\operatorname{IgA}(10-20 \%)$ and a minor fraction of $\operatorname{IgE}$ and $\operatorname{IgD}$. IgG is the antibody type most frequently used for immunoassay. It occurs in four different forms: $\mathrm{IgG} 1-\mathrm{IgG} 4$. IgG is produced in the human body by B-lymphocytes approximately one week after exposure to the antigen. In comparison, $\operatorname{IgM}$ is produced shortly after exposition and it is typically specific to lipopolysaccharides (LPS) and other glycosylated macromolecules (Pohanka 2007). IgG has a molecular weight of $155 \mathrm{kDa}$ and consists of two heavy (approx. $50 \mathrm{kDa}$ ) type chains $\gamma$ and two light $(22-25 \mathrm{kDa})$ chains type $\kappa$ or $\lambda$. The light chains $\kappa$ and $\lambda$ are common to the whole group of immunoglobulins. The structure of $\operatorname{IgG}$ is schematically similar to the shape of letter Y. The structure of a typical IgG is clearly depicted in Fig. 1. IgG has two binding sites - paratopes - on the two so-called Fab regions including the variable and constant part of the light chain $\left(\mathrm{V}_{\mathrm{L}}\right.$ and $\left.\mathrm{C}_{\mathrm{L}}\right)$ and the variable plus one from three parts of the heavy chain $\left(\mathrm{V}_{\mathrm{H}}\right.$ and $\left.\mathrm{C}_{\mathrm{H}} 1\right)$. The constant part from the two heavy chains $\mathrm{Fc}\left(\mathrm{C}_{\mathrm{H}} 2\right.$ and $\mathrm{C}_{\mathrm{H}} 3$ domains) plays an important role in the immune response and allows binding to tissue cells, complement and/or T and B lymphocytes. The most important role of the $\mathrm{Fc}$ part in immunoassays is the convenient orientation of the paratope due to its fixation in the Fc region. Fc and even Fab regions are glycosylated but the most glycosylated is the $\mathrm{C}_{\mathrm{H}} 2$ domain (Dwek et al. 1995). The IgG molecule can be selectively fragmented by some enzymes. Papain cuts the heavy chains between the $\mathrm{C}_{\mathrm{H}} 1$ and $\mathrm{C}_{\mathrm{H}} 2$ domains before the hinge region. Two Fab and $\mathrm{Fc}$ fragments are formed. Pepsin is able to degrade the Fc part behind the hinge region so that the $\mathrm{F}(\mathrm{ab})_{2}$ fragment remains (Parr 1977).

Although not commonly used for analytical purposes, other immunoglobulins besides IgG, would be suitable. $\operatorname{IgM}$ is one of the greatest immunoglobulins. This is a pentameric structure where the Fc parts are bound in a circle by the $\mathrm{J}$ chain resulting in a final weight of $900 \mathrm{kDa}$. The heavy chain is the $\mu$ type. On the other hand, because of a pentameric structure offering ten binding sites, IgM can initiate the creation of highly crosslinked precipitates. Because of this pentameric structure, the inactivation of the paratope by immobilization is not common compared to the immobilization of $\mathrm{IgG}$. Immunoglobulins A are produced by plasmatic cells near mucous membranes especially the intestine. It has a dimeric structure (occasionally monomeric and trimeric) connected by the $\mathrm{J}$ chain and including secretion particles for membrane penetration. The heavy chain is of the $\alpha$ type. The molecular weight of IgA increases in the range from 160 (monomer) -370 (dimer) - $1000 \mathrm{kDa}$ (trimer) with secretion particles. Immunoglobulins A have only minimal importance as recognition elements in analytical devices but some immunization schemas for IgA secretion have appeared in model systems (Externest et al. 2000). $\mathrm{IgE}$ is present in human serum in very low concentrations; its main targets are multicellular parasites and it frequently participates in allergic reactions. The heavy chain is $\varepsilon$ type and it is largely glycosylated. IgE has a monomeric structure with a molecular weight of $190 \mathrm{kDa}$. IgD is a receptor on the surface of B-cells and although free in serum is in only relatively low concentrations; its molecular weight is $180 \mathrm{kDa}$. Both IgE and IgD have minimal importance in immunoanalytical methods even though a large glycosylation in their Fc parts could be an advantage for labeling.

\section{PRODUCTION AND PURIFICATION OF ANTIBODIES}

Antibodies can be distinguished according to the number of B-lymphocyte lines that produce them. Polyclonal antibodies are produced from different B-lymphocyte lines as a mixture of immunoglobulins. The monoclonal antibody is a product of one clone of B-lymphocyte. A specific issue is the preparation of recombinant antibodies (Emanuel et al. 2000) where genetic manipulation is applied and the producing cell would be of different origin.

Many purification methods have been developed for the production of crude antibodies over past decades. Since the molecules of immunoglobulins are 


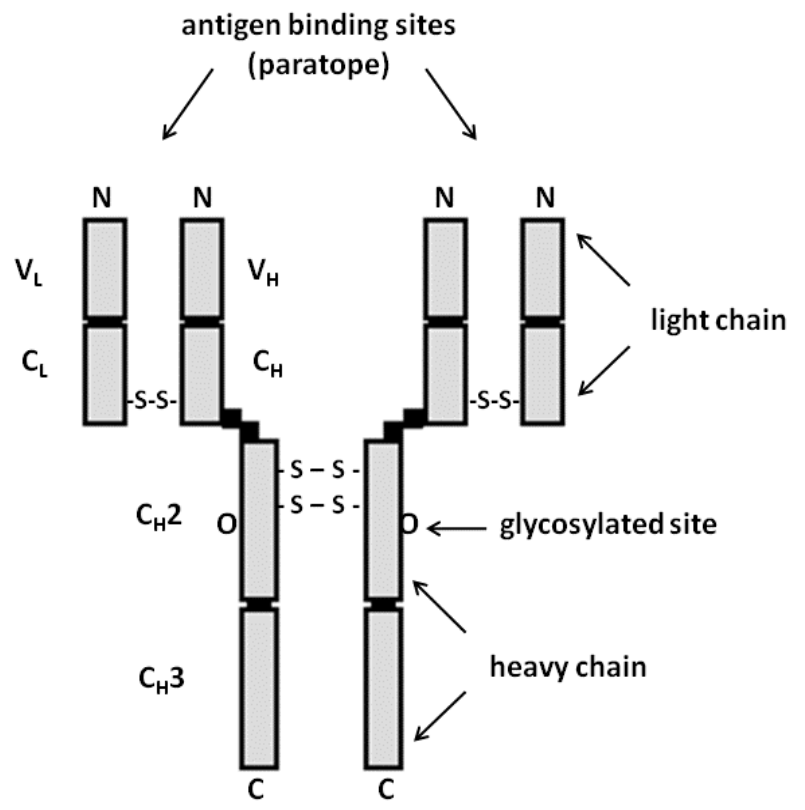

Fig. 1. Schematic structure of immunoglobulin G.

typical proteins, current methods for protein purification are suitable also for the purification of immunoglobulins. For example gel chromatography is one convenient method for separating IgG from the IgM present in polyclonal antibody samples. Precipitation by ammonium sulfate is able to divide the isotypes of immunoglobulins (Bergmann-Leitner et al. 2008). Compounds using pathogenic bacteria for their defense against a hostile immune system are convenient for both affinity chromatography and solid phase extraction (Akerström et al. 1987, Ventury et al. 2000). Proteins A, G and L are very common and commercially supplied either free or bound to supports such as agarose. Antibodies can be simply purified by solid phase extraction using only a matrix with the intercepted protein A, G and/or L (Pohanka et al. 2007). Another suitable bio-ligand is an antibody specific against either a whole Ig group or to one class or subclass of immunoglobulins. Compounds prepared by organic synthesis such as mercaptoethyl pyridine are successful alternatives to biologically derived ligands.

\section{PRODUCTION OF POLYCLONAL ANTIBODIES}

For a laboratory allowed and equipped to work with living animals, the preparation of polyclonal antibodies remains the simplest method in comparison with alternative approaches (Pohanka et al. 2008). Antibodies against pathogens are produced naturally in organisms after the start of an infection but many different antigens are non-pathogenic organisms or simpler macromolecular structures, so there is a risk of inducing tolerability or a hypersensitive reaction. For these reasons, the application of adjuvants is necessary in typical immunisation schemas. Among classical options are Freund's adjuvants, including Freund's complete adjuvant (FCA) and Freund's incomplete adjuvant (FIA). FCA is a water-in-oil emulsion with surfactant mannide monoleate and extracts from Mycobacterium tuberculosis and Mycobacterium butyricum. It is a highly toxic substance and in the immunization protocol, may be used only once. FIA does not include extracts from M. tuberculosis and M. butyricum, is less effective than FCA, but is less toxic to the immunized organism. A combination of FIA and FCA is usually optimal. Another widely known adjuvant is the Ribi adjuvants system. It is an oil-in-water emulsion including squalene, surfactant Tween 80 and some parts from Mycobacterium sp. This system is less effective than FCA, but on the other hand it is less toxic. Titermax is another interesting alternative. It was developed by team headed by Rober L. Hunter in the early 1980's. The main advantage of titermax is the presence only of definable organic compounds with reduced toxicity. This adjuvant titermax includes no biological materials. It is based on the organic copolymers polyoxypropylene and polyoxyethylene, 
squalene and some other ingredients. Titermax is comparably effective to FCA but it lacks acute toxic side effects.

An important issue in the production of a polyclonal antibody is the selection of a convenient animal. Outbreeding animals are cheaper but there is poor reproducibility in comparison with inbreeders. The specificity of polyclonal antibodies can be improved when specific pathogen free (SPF) animals are used. The immune system of SPF animals is "tabula rasa". On the other hand, SPF animals may be inclined to high mortality due to the naivety of their immune system. For polyclonal antibody production, animals such as goats, pigs, hamsters, horses, rats, mice, and sheep should be chosen; however, rabbits seem to be the most convenient for these purposes (Morris and Stanley 2003). Chickens or eggs may be used but avian antibodies have a slightly different structure from mammalian ones. The required amount of antibody and the availability of a menagerie are also important parameters of choice.

Polyclonal antibodies can be prepared against whole microorganisms; their preparation has also been reported using rabbits immunizated by peptides such as two fragments - bacteriocin and pediocin PA-1 from Pediococcus acidilactici conjugated to the carrier protein keyhole limpet hemocyanin (Martínez et al. 1998) and fragments of human chaperonin 10 bound to ovalbumin (Somodevilla-Torres et al. 2000). The polyclonal antibody can even be prepared against small molecules such as organophosphate when haptenized; for example organophosphate paraoxon conjugated with BSA was used for the immunization of New Zealand rabbits (Heldman et al. 1985). The conjugate BSA-paraoxon was emulsified in a complete Freund's adjuvant and was administered at four doses at 2-4 weeks intervals resulting in production with hyperimmunized serum.

\section{PRODUCTION OF MONOCLONAL ANTIBODIES}

Monoclonal antibodies are identical antibodies produced by the hybridized cloning of immortalized B-lymphocyte originating from one parent cell. Hybridoma technology was used for the production of monoclonal antibodies by Köhler and Milstein (1975). Scheme of hybridoma technology is depicted in Fig. 2. At the beginning of the process of antibody production, the laboratory animal is immunized. The B-lymphocytes from either spleen or lymph nodes from the laboratory animal are isolated and are fused with mutant myeloma cells in the presence of polyethylene glycol. For the selection of fused cells from the original unfused ones the selective HAT (hypoxanthine-aminopterin-thymidine) medium is used. Normal cells include the main pathway for nucleotide synthesis and an alternative pathway based on the enzyme hypoxanthine-guanine phosphoribosyltransferase (HGPRT). The myeloma cells employed have damaged genes for HGPRT; the 8 -azaguanine will kill cells translating the HGPRT enzyme. If the main pathway for nucleotide synthesis is inhibited by aminopterin, only fused cells (hybridomas) including genes for HGPRT from B-lymphocytes are able to grow and metabolize hypoxanthine. The non-fused B-lymphocytes are not able to grow at all and non-fused myeloma cells are not able to employ hypoxanthine so they do not have a sufficient pool of nucleotides for growth.

The hybridomas thus obtained produce specific antibodies. The culture of hybridomas is diluted up to a single cell per microplate well and colonies resulting from each individual cell are consequently cultured. Antibodies come from one clone. The antibody thus prepared is monospecific. Every colony should be tested and the colonies producing antibodies with the desired properties can be cultivated, allowing the production of antibodies in large quantities. Stocks of the cell line can be kept frozen for an unlimited time. The monoclonal antibody can also be produced in live animals. When the hybridoma cells are injected into the laboratory animal, they produce tumours containing an antibody rich solution - ascites fluid. This technique is very painful for animals, is often considered unethical, and thus the production of monoclonal antibodies in fermentation chambers is currently preferred.

Monoclonal antibodies have been prepared for large number of antigens including small molecules such as the organophosphate soman (Erhard et al. 1990) or larger structures such as the LPS surface antigen 0157 from E. coli (Laegreid et al. 1998). Monoclonal antibodies could be prepared also for the assay of whole cells such as Listeria monocytogenes; Crowley et al. (1999) used prepared antibodies for the construction of an amperometric immunosensor as well as ELISA. In other studies, monoclonal antibodies against the cell wall proteins of Bifidobacterium longum (Amrouche et al. 2006) and B. anthracis lethal toxin (Little et al. 1990) were prepared in suitable amounts and quality. A technique for the production of human monoclonal antibodies of an appropriate isotype against selected antigens is possible by employing mice and standard hybridoma technology (Mendez et al. 1997); the original Ig loci in mice are reconstituted with human ones. The antibodies thus prepared are tolerated by the human 


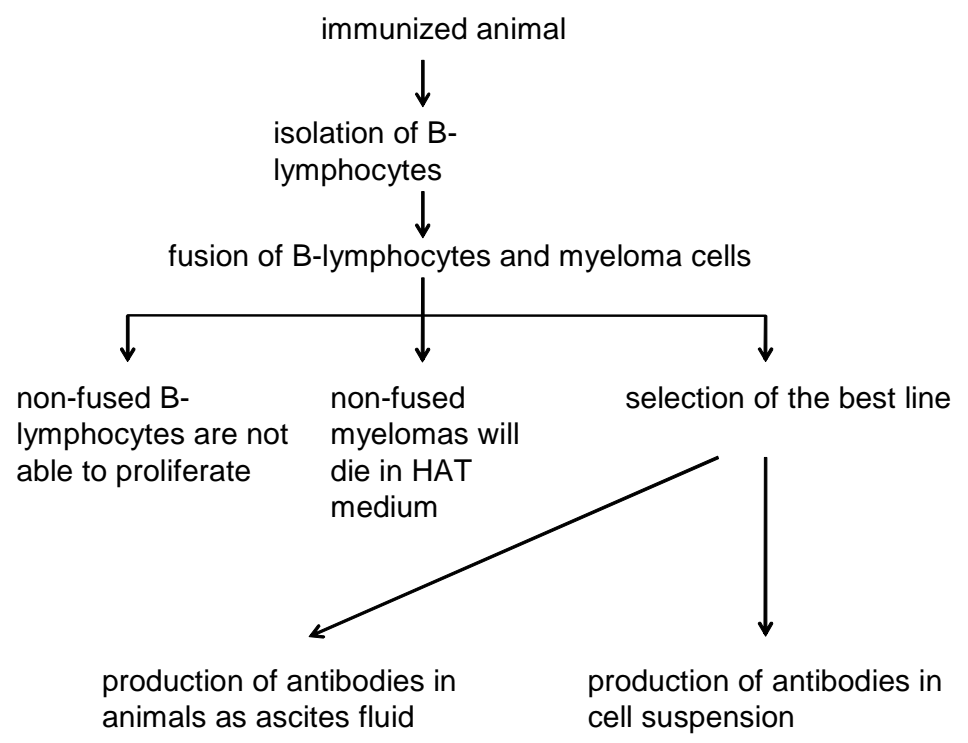

Fig. 2. Blocking scheme of monoclonal antibody production.

body and this could be promising for some specific treatments as well as diagnoses. The antibody with specificity to the LPS $\mathrm{O}$ side chain antigen from Pseudomonas aeruginosa generated from mice is a practical example of a humanized monoclonal antibody (Hemachandra et al. 2001).

\section{EXAMPLES OF THE APPLICATION OF ANTIBODIES}

Antibodies are a necessary part of many devices. ELISA kits for the diagnosis of infectious diseases, the levels of specific markers such as the marker of inflammation cyclooxigenase 2 are typical examples (Kowal-Bielecka et al. 2005). An example of a complex technical instrument using antibodies as a recognition element is the RAPTOR device developed in the Naval Research Laboratory (Washington DC, USA) in the 1990s. This portable device is based on a completely automated fiber optic biosensor for simultaneous detection of four different biological agents in 3-10 minutes. The assay scheme was classical: fibers were covered by primary antibodies; the complex with analyte is closed by the second antibody labeled Cy-5. The system was used, for example, by Anderson et al. (2000) for the laboratory detection of the following biological warfare agents (in brackets are shown the limits of detection): Bacillus globigii $\left(5 \times 10^{4} \mathrm{CFU} / \mathrm{ml}\right.$; mimetic of B. anthracis), Francisella tularensis $\left(5 \times 10^{5}\right.$ $\mathrm{CFU} / \mathrm{ml}$ ), and staphylococcal enterotoxin (SEB; $10 \mathrm{ng} / \mathrm{ml})$ and ricin $(50 \mathrm{ng} / \mathrm{ml})$.

Pohanka and Skládal (2007) used the polyclonal antibody immobilized via protein A to construct a piezoelectric biosensor based on quartz crystal microbalance (QCM). The biosensor was found useful for the label-free detection of F. tularensis. A limit of detection of $10^{5} \mathrm{CFU} / \mathrm{ml}$ in buffer and $10^{6}$ $\mathrm{CFU} / \mathrm{ml}$ was achieved when $F$. tularensis was attenuated by $0.5 \%$ phenol. Antibodies can be widely used for assays of mycotoxins as an alternative to the more elaborative instrumental techniques (Kolosova et al. 2006, Pohanka et al. 2008b); for example, two mycotoxins, aflatoxin B1 and ochratoxin A, were assayed by a tandem immunoassay column and competitive ELISA (Goryacheva et al. 2007). They reached a limit of detection of 5 (aflatoxin B1) and 10 (ochratoxin A) $\mu \mathrm{g} / \mathrm{kg}$.

\section{CONCLUSIONS}

Antibodies are a wide group of molecules suitable for specific interaction with analytes. A continuous effort to prepare antibodies is necessary to develop 
immunoassay. This study describes techniques necessary for the production of antibodies and their purification. Monoclonal as well as polyclonal antibodies seem to be promising for analytical purposes as can be seen from the examples given. Though the production of antibodies is quite cheap, it is still necessary to use laboratory animals and thus the ethical aspect of antibodies production should be also taken into account.

\section{ACKNOWLEDGEMENT}

Ministry of Defence of the Czech Republic is gratefully acknowledged for project No. FVZ0000604.

\section{REFERENCES}

Amrouche T, Boutin Y, Moroni O, Kheadr E, Fliss I: Production and characterization of anti-bifidobacteria monoclonal antibodies and their application in the development of an immuno-culture detection method. J Microbiol Methods 65:159-170, 2006.

Anderson GP, King KD, Faffney KL, Johnson LH: Multi-analyte interrogation using the fiber optic biosensor. Biosens Bioelectron 14:771-777, 2000.

Akerström B, Nielsen E, Björck L: Definition of the IgG- and the albumin-binding regions of streptococcal protein G. J Biol Chem 262:13388-13391, 1987.

Bergmann-Leitner ES, Mease RM, Duncan EH, Khan F, Waitumbi J, Angov E: Evaluation of immunoglobulin purification methods and their impact on quality and yield of antigen-specific antibodies. Malar J 7:129, 2008.

Crowley EL, O'Sullivan CK, Guilbault GG: Increasing the sensitivity of Listeria monocytogenes assays: evaluation using ELISA and amperometric detection. Analyst 124:295-299, 1999.

Dwek RA, Lellouch AC, Wormald MR: Glycobiology: "the function of sugar in the $\mathrm{IgG}$ molecule". J Anat 187:279-292, 1995.

Emanuel PA, Dang J, Gebhardt JS, Aldrich J, Garber EAE, Henrieta K, Stopa P, Valdes JJ, Schultz AD: Recombinant antibodies: a new reagent for biological agent detection. Biosens Bioelectron 14:761-770, 2000.

Erhard MH, Kuhlmann R, Szinicz L, Losch U:
Detection of the organophosphorus nerve agent soman by an ELISA using monoclonal antibodies. Arch Toxicol 64:580-585, 1990.

Externest D, Mackelein B, Schmidt MA, Frey A: Correlations between antibody immune responses at different mucosal effector sites are controlled by antigen type and dosage. Infect Immun 68:3830-3839, 2000.

Goryacheva IY, DeSaeger S, Delmulle B, Lobeau M, Eremin SA, Barna-Vetro I, Van Peteghem C: Simultaneous non-instrumental detection of aflatoxin A using a clean-up tandem immunoassay column. Anal Chim Acta 590:118-124, 2007.

Heldman E, Balan A, Horowitz O, Ben-Zion S, Torten M: A novel immunoassay with direct relevance to protection against organophosphate poisoning. FEBS Lett 180:243-248, 1985.

Hemachandra S, Kamboj K, Copfer J, Pier G, Green LL, Schreiber JR: Human monoclonal antibodies against Pseudomonas aeruginosa lipopolysaccharide derived from transgenic mice containing megabase human immunoglobulin loci are opsonic and protective against fatal pseudomonas sepsis. Infect Immun 69:2223-2229, 2001.

Köhler G, Milstein C: Continuous cultures of fused cells secreting antibody of predefined specificity. Nature 256:495-497, 1975.

Kolosova AY, Shim WB, Yang ZY, Eremin SA, Chung DH: Direct competitive ELISA based on a monoclonal antibody for detection of aflatoxin B1. Stabilization of ELISA kit components and application to grain samples. Anal Bioanal Chem 384:286-294, 2006.

Kowal-Bielecka O, Kowal K, Distler O, Rojewska J, Bodzenta-Lukaszyk A, Michel BA, Gay RE, Gay S, Sierakowski S: Cyclooxygenase-and lipoxygenase-derived eicosanoids in bronchoalveolar lavage fluid from patients with scleroderma lung disease: an imbalance between proinflammatory and antiinflammatory lipid mediators. Arthritis Rheum 52:3783-3791, 2005.

Laegreid W, Hoffman M, Keen J, Elder R, Kwang J: Development of a blocking Enzyme-Linked Immunosorbent Assay for detection of serum antibodies to $\mathrm{O} 157$ antigen of Escherichia coli. Clin Diagn Lab Immunol 5:242-246, 1998.

Little SF, Leppla SH, Friedlander AM: Production and characterization of monoclonal antibodies against the lethal factor component of Bacillus anthracis lethal toxin. Infect Immun 58:1606-1613, 1990.

Martínez JM, Martínez MI, Suárez AM, Hezzanz C, Casaus P, Cintas LM, Rodríguez JM, Hernández PE: Generation of polyclonal antibodies of 
predetermined specificity against pediocin PA-1. Appl Environ Microbiol 64:4536-4545, 1998.

Mendez MJ, Green LL, Corvalan JR, Jia XC, Maynard-Currie CE, Yang XD, Gallo ML, Louie DM, Lee DV, Erikson KL, Luna J, Roy CM et al.: Functional transplant of megabase human immunoglobulin loci recapitulates human antibody response in mice. Nat Genet 15:146-156, 1997.

Morris TJ, Stanley EF: A simple method for immunocytochemical staining with multiple rabbit polyclonal antibodies. J Neurosci Methods 127:149-155, 2003.

Nimmo GR, Lew AM, Stanley CM, Steward MW: Influence of antibody affinity on the performance of different antibody assays. J Immunol Methods 72:177-187, 1984.

Parr DM: Fragments produced by digestion of human immunoglobulin $\mathrm{G}$ subclasses with pepsin in urea. Biochem J 165:303-308, 1977.

Pasupathi P, Bakthavathsalam G, Saravanan G, Devaraj A: Changes in $\mathrm{CD}^{4+}$ cell count, lipid profile and liver enymes in HIV infection and AIDS patients. J Appl Biomed 6:139-145, 2008.

Pohanka M: Evaluation of immunoglobulin production during tularaemia infection in $\mathrm{BALB} / \mathrm{c}$ mouse model. Acta Vet Brno 76:579-584, 2007.

Pohanka M, Skládal P: Piezoelectric immunosensor for the direct and rapid detection of Francisella tularensis. Folia Microbiol 52:325-330, 2007.

Pohanka M, Skládal P: Electrochemical biosensors principles and applications. J Appl Biomed 6:57-64, 2008.

Pohanka M, Pavliš O, Skládal P: Diagnosis of tularemia using piezoelectric biosensor technology. Talanta 71:981-985, 2007.

Pohanka M, Pavliš O, Kroča M: ELISA detection of Francisella tularensis using polyclonal and monoclonal antibodies. Def Sci J 58:698-702, 2008a.

Pohanka M, Malíř F, Roubal T, Kuča K: Detection of aflatoxins in Capsicum spice using an electrochemical immunosensor. Anal Lett 41:2344-2353, 2008b.

Somodevilla-Torres MJ, Hillyard NC, Morton H, Alewood D, Halliday JA, Alewood PF, Vesey DA, Walsh MD, Cavanagh AC: Preparation and characterization of polyclonal antibodies against human chaperonin 10. Cell Stress Chaperones 5:14-20, 2000.

Tejral G, Panyala NR, Havel J: Carbon nanotubes: toxicological impact on human health and environment. J Appl Biomed 7:1-13, 2009.

Ventury M, Rimon A, Gerchman Y, Hunte C, Padan E, Michel H: The monoclonal antibody 1F6 identifies a $\mathrm{pH}$-dependent conformational change in the hydrophilic $\mathrm{NH}_{2}$ terminus of $\mathrm{NhaA} \mathrm{Na}^{+} / \mathrm{H}^{+}$ antiporter of Escherichia coli. J Biol Chem 18:4734-4742, 2000. 